\title{
Exploring Gothic Sexuality
}

\author{
Michael Eberle-Sinatra Université de Montréal
}

There are no facts, only interpretations.

(Nietzsche)

In his well-known analysis of the evolution of sexuality in society in Making Sexual History, Jeffrey Weeks comments that, following a series of major challenges throughout the twentieth century (ranging from Freud's work to the challenges of feminism and queer politics), 'sexuality becomes a source of meaning, of social and political placing, and of individual sense of self'. ${ }^{1}$ This special issue of Gothic Studies intends to foster further research on the topic of queer sexuality. This is research which has, of course, already been underway for some time - but it has not always been interdisciplinary in nature, as is the case for all five articles, in their discussion of theatre, cinema, and literature or literary conventions borrowed from Gothic novels, included here. There are encouraging signs for the future, though. A recent special issue of Romanticism on the Net, guest-edited by Michael O'Rourke and David Collings, engages directly with queer theory and Romantic literature, and fittingly complements this special issue with an attention to the early years of the Gothic and more theoretical discussions about queer theory. ${ }^{2}$ Both issues will then, I hope, generate more discussion on the Gothic genre in its various manifestations and be of interest to Gothicists at large.

It is obviously beyond the purpose of this brief introduction to engage with the history of queer theory, a history which is, as Donald E. Hall puts it, 'a problematic one'. ${ }^{3}$ My choice of title for this special issue and the articles included in it was based on the work of Ellis Hanson and Robert Lang in their studies of films and queer theory, and Hanson's definition of the term 'queer' in the sense in which it refers to 'a rejection of the compulsory heterosexual code of masculine men desiring feminine women'. ${ }^{4}$ Of course, an interpretative exploration of this kind is inconclusive by nature. Rather than draw a firm conclusion on the presence or absence of homosexuality in the works under consideration in this special issue, I want to suggest that each author encourages readers to think carefully about the assumptions with which they approach the sexuality of the characters found in 
these films and novels. Indeed, every work under consideration contains a number of social clues about their characters that could be read in quite a different light than the majority of criticism published so far would suggest. The five essays included in this special issue share an interest in exploring gender issues that would best be described by the loaded term 'queer', even if none of the contributors engage directly with the works of Michel Foucault or Judith Butler. I hope that this special issue will contribute further to a discussion of the sexuality of male and female characters, particularly when they do not adhere exclusively to the heterosexual norm.

Bearing in mind the title of this special issue, 'Queering Gothic Films', the question, one might argue, is not which Gothic films are 'queer' but rather which ones are not, for the Gothic has long been associated with different sexualities. The idea of transgressing boundaries and social norms of family have resulted in an ostracization of Gothic novels from the publication of Matthew Lewis's famous novel The Monk onward. ${ }^{5}$ After the impact of science and psychoanalysis on Gothic works, the cinema in turn has allowed for a visualization of these ranges of concerns. The essays included in this special issue range from a discussion of film adaptations of classic Gothic novels - Mary Shelley's Frankenstein and Bram Stoker's Dracula - to a reworking of Gothic convention within the science-fiction genre, a genre for which Mary Shelley has been aptly named the mother figure (alongside the two father figures, H. G. Wells and Jules Verne).

In this context, the inclusion of Frank Capra's $1944 \mathrm{film}$ Arsenic and Old Lace might seem, dare I say it, a queer choice as the opening essay for this special issue. Yet, as Jason Haslam's essay "'A Secret Proclamation": Queering the Gothic Parody of Arsenic and Old Lace' demonstrates, it is in fact on the one hand the perfect example of the shift from theatre to cinema (similar to James Whale's 1931 classic film version of Frankenstein based on a play and not directly upon Shelley's novel) and the questions raised in the translation from one medium into another. On the other hand, Haslam's exploration of the parodic elements in Capra's film attests to the pervasiveness of Gothic elements and queer sexuality in mainstream cinema, as well as the fluidity of gender construction. Although not one of Capra's best known films, Arsenic and Old Lace offers a fascinating reading of the construction of the American family, including the unusual members of Cary Grant's family. The Gothic tropes used in this film successfully present a new version of sexuality that is definitely queer, although the point is not to assert a predominant homosexual relationship in these texts as much as to continue the Gothic's own destabilization of gender roles, a destabilization best exemplified in the character of Ripley in the science-fiction series Alien.

If Gothic novels were somehow lacking strong female characters, arguably because of contemporary role value - think of Catherine Morland in Jane Austen's witty parody Northanger Abbey - Ripley is one of the early figures of American science fiction cinema to challenge gender stereotype in her incredible resistance and ability to survive not only the first encounter with an Alien in the eponymous film made by Ridley Scott in 1979, but also in the following two sequels. Ripley's 
uncharacteristic behavior predates Linda Hamilton and her transformation from waitress to pre-apocalyptic warrior in James Cameron's 1984 Terminator and its sequel Terminator 2: Judgment Day. ${ }^{6}$ If a reading that brings together some of the classic eighteenth-century Gothic novels and one of the most famous sciencefiction series like Alien seems far-fetched for some, it is worth bearing in mind Lauren Fitzgerald's insightful comment that

[t]he films draw not only on stock conventions of Gothic architecture, such as labyrinthine tunnels and cathedral-like vaults, but, to propel the plots, the Gothic dynamic of heroine versus villain, pitting the determined Ellen Ripley (Sigourney Weaver) against both the unnatural horrors of the aliens and the avarice of a militaryindustrial complex. ${ }^{7}$

Technology in the Alien films thus provides another setting for exploring alternative sexualities in ways that evoke early Gothic novels, especially in their challenge to the family unit.

The representation of unusual families is at the core of Lorena Russell's 'Queer Gothic and Heterosexual Panic in the Ass-End of Space' in her reading of Alien ${ }^{3}$ and the sexual politics at play on the Gothic setting of Fury 161, the planet on which Ripley crashes. Russell expands on Ross Jenning's discussion of Ripley as a key lesbian representation in the 1990s and of the film's play with 'sexual difference and sameness.' Russell also sets up Brenda M. Boyle's complimentary essay 'Monstrous Bodies, Monstrous Sex: Queering Alien Resurrection' and its engagement with the representation of monsters, along the line of works by Judith Halberstam and Harry Benshoff. Russell's thought-provoking redefinition of the monster in Gothic and sexual terms in turn anticipates Christopher McGunnigle's 'My Own Vampire: The Metamorphosis of the Queer Monster in Francis Ford Coppola's Bram Stoker's Dracula' and its detailed criticism of Francis Ford Coppola's 1992 film adaptation of Bram Stoker's Gothic novel, one that stands shoulder to shoulder with Mary Shelley's Frankenstein for the largest number of film adaptations over the last hundred year. Adaptations, as Robert Stam rhetorically puts it, "adapt to" changing environments and changing tastes, as well as to a new medium, with its distinct industrial demands, commercial pressures, censorship taboos, and aesthetic norms, 9 and Coppola's film certainly fits this description. McGunnigle analyzes the vampire's gender deconstruction in Stoker's novel and Coppola's film as expressed in the werewolf-like creature McGunnigle describes as the 'Wild Thing. This 'Wild Thing' is, according to the author, a direct threat to sexual norms, one that within the film echoes the perversity of Frank-N-Furter in The Rocky Horror Picture Show, or least the perceived perversity as I discuss in my essay 'Readings of Homosexuality in Mary Shelley's Frankenstein and Four Film Adaptations'. This essay takes this special issue back to one of the original texts, one that reinvigorated the Gothic genre at the beginning of the nineteenth century and set in motion a new series of paradigm with its scientific components and its subtle yet effective challenge to mainstream sexuality. It now remains for me to bid this special issue, my own 'hideous progeny', to go forth and prosper. 


\section{Notes}

1 Jeffrey Weeks, Making Sexual History (London: Polity Press, 2000), p. 169.

2 The issue is available online at http://www.erudit.org/revue/ron/2004/v/n36-37/ index.html.

3 Donald E. Hall, Queer Theories (Basingstoke: Palgrave Macmillan, 2003), p. 21.

4 Ellis Hanson, 'Introduction' to Out Takes: Essays on Queer Theory and Film (Durham, NC: Duke University Press, 1999), p. 4.

5 For a longer discussion of religion and sexuality, see George Haggerty's article 'The Horrors of Catholicism: Religion and Sexuality in Gothic Fiction', Romanticism on the Net 36-7 (November 2004-February 2005), available on-line at http://www.crudit. org/revue/ron/2004/v/n36-37/011133ar.html.

6 Interestingly enough, Cameron's films are direct descendants of Shelley's famous progeny and the continuing struggle between scientific advances, problematic responsibility, and the consequences of humanity's innovation in creating artificial life. This is a theme that has been recurrent in science fiction novels since Isaac Asimov's 1940s friendly robots and Philip K. Dick's less friendly replicants in his 1968 novel Do Androids Dream of Electric Sheep?, to William Gibson's 1984 Neuromancer and its own cinematic progeny found in the Wachowski brothers' trilogy The Matrix.

7 Lauren Fitzgerald, '(In)alienable Rights: Property, Feminism, and the Female Body from Ann Radcliffe to the Alien Films,' Romanticism On the Net, 21 (February 2001), unpaginated, available online at http://www.erudit.org/revue/ron $/ 2001 / \mathrm{v} / \mathrm{n} 21$ / 005961ar.html.

8 Ross Jenning, 'Desire and Design: Ripley Undressed', in Wilton Tamsin, ed., Immortal, Invisible: Lesbians and the Moving Image (London: Routledge, 1995), p. 202.

9 Robert Stam, 'The Theory and Practice of Adaptation', Literature and Film: A Guide to the Theory and Practice of Film Adaptation, ed. Robert Stam and Allesandra Raengo (Malden, MA and Oxford: Blackwell Publishing, 2005), p. 3.

\section{Address for Correspondence}

Michael Eberle-Sinatra, Département d'études anglaises, Université de Montréal, CP 6128 , Station Centre-ville, Montréal, Quebec H3C3J7, Canada 